Bali Medika Jurnal.

Vol 7 No 2, 2020: 20-28

ISSN : 2615-7047

DOI: https://doi.org/10.36376/bmj.v7i2

Disubmit 5 Oktober 2020

Diterima 27 Desember 2020

\title{
HUBUNGAN OBESITAS SENTRAL TERHADAP MENARCHE DINI PADA REMAJA PUTRI DI SMP NEGERI 3 ABIANSEMAL
}

\section{RELATIONSHIP BETWEEN CENTRAL OBESITY AND EARLY MENARCHE IN TEENAGERS AT SMP NEGERI 3 ABIANSEMAL}

\author{
Made Ayu Desyana Wulandari ${ }^{1}$, I Dewa Putu Gede Putra Yasa ${ }^{2}$, I Made Duita ${ }^{3}$ \\ Sekolah Tinggi Ilmu Kesehatan Wira Medika Bali, Indonesia ${ }^{123}$
}

\begin{abstract}
ABSTRAK
Menarche merupakan suatu pertanda dimulainya siklus masa subur pada remaja putri yang dipengaruhi oleh beberapa faktor salah satunya yaitu obesitas sentral. Penelitian ini bertujuan untuk mengetahui hubungan antara obesitas sentral degan kejadian menarche dini pada remaja putri di SMP Negeri 3 Abiansemal. Penelitian ini menggunakan desain deskriptif analitik dengan pendekatan cross sectional, pada sampel sebanyak 163 orang yang dipilih dengan teknik probability multistage random sampling dari seluruh siswa putri di SMP Negeri 3 Abiansemal. Pengumpulan data dilakukan dengan melakukan pengukuran lingkar pinggang dan mengidentifikasi usia menarche. Hasil penelitian menunjukkan bahwa sebanyak 57 responden (34,97\%) mengalami obesitas sentral dan yang mengalami menarche dini sebanyak 89 responden $(54,60 \%)$. Hasil uji chi square didapatkan hasil $\mathrm{p}$ value sebesar 0,000 dari tingkat signiikansi ditentukan yaiu 0,05 . Sehingga dapat disimpulkan ada hubungan bermakna antara obesitas sentral dengan kejadian menarche dini.
\end{abstract}

Kata Kunci: Obesitas Sentral, Menarche Dini, Remaja Putri

\section{ABSTRACT}

Menarche is a sign of fertility cycle that began in teenager caused by several factors. One of them is central obesity. This study aims to determine relationship between central obesity and early menarche in teenagers at SMP Negeri 3 Abiansemal. This research applies descrivtive analytic designs with cross sectional approach, the number of samples are 163 respondents by using multistage random sampling of all female students at SMP Negeri 3 Abiansemal. The data was collected by waist circumference and age of menarche identified. The result shows from 163 respondents 57 respondents $(34,97 \%)$ are central obesity and early menarche is 89 respondents $(56,60 \%)$. The results of chi square analysis test obtained $p$ value of 0,000 from the specified significance level of 0,05. In conclusion, there is a significant relationship between central obesity and early menarche.

Keywords: Obesity, Early Menarche, Teenagers

\begin{tabular}{ll}
\hline Alamat Korespondensi & : Banjar Agung Mambal, Kecamatan Abiansemal, Kabupaten \\
& $\begin{array}{l}\text { Badung, Bali 80352 } \\
\text { Email }\end{array}$
\end{tabular}




\section{PENDAHULUAN}

Masa remaja merupakan salah satu periode dari perkembangan manusia. "Masa remaja merupakan masa perubahan atau peralihan dari masa kanak-kanak ke masa dewasa yang meliputi perubahan biologik, perubahan psikologik, dan perubahan sosial. Sebagian besar masyarakat dan budaya masa remaja pada umumnya dimulai pada usia 10-13 tahun dan berakhir pada usia 18-22 tahun" (Notoatmodjo, 2007). Sebelum memasuki masa remaja, seseorang akan mengalami periode pubertas terlebih dahulu. Pada periode pubertas inilah akan terjadi percepatan pertumbuhan dan perkembangan fisik dari anak-anak menjadi dewasa serta mengalami kematangan organ reproduksi seksual. Masa pubertas pada wanita ditandai oleh pertumbuhan fisik yang cepat, menarche, perubahan psikologis dan timbulnya ciri-ciri kelamin sekunder (Susanti, 2012).

Menarche merupakan peristiwa paling penting pada remaja putri sebagai pertanda siklus masa subur sudah dimulai (Rosidah, 2008). Menarche diartikan sebagai permulaan menstruasi pada seorang gadis pada masa pubertas. Pada remaja putri banyak hal-hal yang dapat mempengaruhi menarche, antara lain adanya perubahan hormon yang mempengaruhi kematangan sel dan asupan gizi yang ikonsumsi saat menjelang datangnya menarche (Waryana, 2010). Membaiknya standar kehidupan berdampak pada penurunan usia menarche ke usia yang lebih muda (menarche dini). Kondisi menarche dini ini dikaitkan dengan pubertas prekoks yang terjadi pada anak diusia kurang dari 12 tahun. Peningktan indeks masa tubuh, lemak tubuh dan obesitas dikalangan remaja putri menyebabkan kecenderungan penurunan usia menarche (Susanti, 2012).

Menurut Karapanou \& Papadimitriou (2010), faktor yang mempengaruhi usia menarche dikalangan anak remaja ialah faktor genetik, etnis, psikologis, lemak tubuh, nutrisi dan aktivitas fisikal. Faktor lingkungan tempat tinggal, pendapatan keluarga, besarnya keluarga, dan tingkat pendidikan orang tua juga mempengaruhi perkembangan pubertas pada remaja.

Beberapa faktor yang berhubungan dengan menarche dini diidentifikasi berdasarkan faktor host, faktor agent, dan faktor environment. Faktor host yang terdiri dari usia ibu menarche (genetik), faktor agent terdiri dari status gizi dan konsumsi makanan (konsumsi protein hewani, konsumsi protein nabati, konsumsi lemak, konsumsi serat dan konsumsi kalsium), sedangkan faktor environment terdiri dari keterpaparan media masa orang dewasa (pornografi), perilaku seksual dan gaya hidup (olahraga, konsumsi fastfood, konsumsi softdrink) (Putri \& Soenarnatalina, 2013).

Konsumsi makanan tinggi lemak akan berakibat pada penumpukan lemak dalam jaringan adipose yang berkorelasi positif dengan peningkatan kadar leptin. Leptin ini akan memicu pengeluaran hormone GnEH yang selanjutnya mempengaruhi pengeluaran Follicle Stimulating Hormon (FSH) dan Luteinizing Hormon (LH) dalam merangsang pematangan folikel dan pembentukan estrogen. Akan tetapi hal ini bertolak belakang dengan konsumsi makanan tinggi serat yang dapat menurunkan jumlah kolesterol. Pengaruh ini dikaitkan dengan serat yang dapat menyerap asam empedu yang disintesis dari kolesterol (Susanti, 2012).

Suatu keadaan dimana terjadi akumulasi lemak yang berlebihan atau abnormal yang dapat menganggu kesehatan disebut dengan obesitas ( Suryaputra, 2012). Obesitas sentral merupakan salah satu jenis obesitas dengan penumpukan 
lemak di bagian abdominal tubuh. Obesitas pada anak perempuan membantu timbulnya pubertas dini. Menurut Mundel, EJ 2005 (dalam Sunarto \& Intan, 2010) timbulnya pubertas dini tersebut ditandai dengan terjadinya menarche.

Berdasarkan hasil penelitian yng dilakukan oleh Tolombot, Manampiring, \& Kepel (2014) didapatkan bahwa prevalensi obesitas berdasarkan lingkar pinggang di SMP 8 Manado adalah sebesar 13\%. Berdasarkan hasil Riskesdas 2010 menunjukkan bahwa 37,5\% rata-rata usia menarche pada anak Indonesia adalah 1314 tahun dengan kejadian lebih awal pada usia kurang dari 9 tahun dan ada yang lebih lambat sampai 20 tahun dan 5,2\% anak-anak di 17 provinsi di Indonesia telah memasuki usia menarche dibawah 12 tahun. Indonesia sendiri menempati urutan ke 15 dari 67 negara dengan penurunan usia menarche mencapai 0,145 tahun per decade dari hasil study pendahuluan peneliti pada bulan April 2014, di kelas VII SMP Negeri 3 Abiansemal melalui wawancara langsung kepada siswa didapatkan bahwa sebanyak 172 orang yang mengalami menarche dini yaiu menarche pada umur $\leq 12$ tahun dari 275 orang siswa putri kelas VII.

Berdasarkan penelitian yang dilakukan oleh Susanti (2012) didapatkan prevalensi kejadian menarche dini di SMP Negeri 30 Semarang yaitu 23,6\% dari total populasi kelas VII dengan usia menarche terdini 10 tahun. Risiko menarche dini juga dialami oleh subjek yang memiliki asupan lemak dan kalsium berlebih dengan risiko 4 kali lebih besar dibandingkan mereka yang memiliki asupan lemak dan kalsium tidak lebih. Penelitian dari Sunarto \& Intan (2010) didapatkan bahwa ada hubungan antara kelebihan berat badan dengan menarche dini pada siswi kelas 4,5 dan 6 SD di Wilayah Kecamatan Magetan.

Menurut Halim (2008) (dalam Sunarto \& Intan, 2010) dampak terjadinya menarche dini antara lain terhambatnya pertumbuhan, stress emosional dan peningkatan risiko terjadinya kanker payudara. Menurut Martaadisoebrata (2005) dampat terjadinya menarche dini dapat meningkatnya penyakit menular seksual (PMS) dan kehamilan yang tidak disengaja.

Berdasarkan beberapa penelitian sebelumnya disebutkan bahwa asupan zat gizi yang meliputi asupan lemak, protein (hewani dan nabati), serat dan kalsium berperan penting sebagai penentu usia menarche remaja putri. Namun masih sedikit penelitian yang meneliti mengenai hal tersebut khususnya yang berhubungan dengan obesitas sentral.

Berdasarkan uraian latar belakang diatas maka peneliti tertarik untuk melakukan penelitian mengenai "Hubungan obesitas sentral dengan kejadian menarche dini pada remaja putri di SMP Negeri 3 Abiansemal”.

\section{METODE PENELITIAN}

Penelitian ini merupakan penelitian bersifat kuantitatif dengan desain penelitian yang digunakan yaitu deskriptif analitik yang berarti suatu penelitian yang dilakukan untuk mndiskripsikan atau menggambarkan suatu fenomena yang terjadi didalam masyarakat yang bertujuan untuk menganalisis hubungan obesitas sentral dengan kejadian menarche dini pada remaja putri di SMP Negeri 3 Abiansemal. Rancangan yang digunakan dalam penelitian ini adalah cross sectional yang menekankan watu pengukuran hanya satu kali.

Penelitian ini dilaksanakan di SMP Negeri 3 Abiansemal pada bulan Maret sampai dengan Agustus 2014 dan pengumpulan data dilakukan pada bulan Juni 
2014. Populasi dalam penelitian ini adalah seluruh siswa putri kelas VII di SMP Negeri 3 Abiansemal yang berjumlah 275 orang. Pada penelitian ini sampel yang diambil adalah 163 orang dengan menggunakan teknik sampling probability multistage random sampling yaitu pengembangan dari acak klaster. Pengumpulan data dilakukan dengan melakukan wawancara dan pengukuran lingkar pinggang menggunakan meteran kain dengan skala centimeter. Langkah-langkah pengolahan data dalam penelitian ini adalah dimulai dari editing, coding, entry dan cleaning. Teknik analisis data yang digunakan pada penelitian ini yaitu analisis univariat dan analisis bivariat dengan tingkat signifikansi 0,05. Adapun data yang dianalisis secara univariat meliputi obesitas sentral dan menarche dini. Analisis bivariate dilakukan untuk mengetahui hubungan obesitas sentral dengan menarche dini diuji menggunakan uji Chi Square.

\section{HASIL}

\section{HASIL DAN PEMBAHASAN}

Besar sampel dalam penelitian ini dibentuk menggunakan rumus penentuan sampel (Nursalam, 2013), yakni sebagai berikut:

$$
\begin{aligned}
& n=\frac{N}{1+N\left(d^{2}\right)} \\
& n=\frac{275}{1+275\left(0,05^{2}\right)} \\
& n=\frac{275}{1+0,6875} \\
& n=\frac{275}{1,6875} \\
& n=162,9=163 \text { orang }
\end{aligned}
$$

Table 1. Distribusi frekuensi responden berdasarkan usia pada remaja putri di SMP Negeri 3 Abiansemal

\begin{tabular}{c|c|c}
\hline Usia & $\mathbf{F}$ & $\mathbf{\%}$ \\
\hline $\mathbf{1 1 - 1 2}$ tahun & 26 & $15,95 \%$ \\
\hline $\mathbf{1 3 - 1 4}$ tahun & 137 & $84,05 \%$ \\
\hline Total & 163 & $100 \%$ \\
\hline
\end{tabular}

Berdasarkan tabel 1 diatas menunjukkan bahwa responden yang verusia 1314 tahun sebanyak 137 responden $(84,05 \%)$.

Table 2. Distribusi frekuensi responden berdasarkan lingkar pinggang pada remaja putri di SMP Negeri 3 Abiansemal

\begin{tabular}{c|c|c}
\hline Lingkar pinggang & F & \% \\
\hline Obesitas sentral & 104 & $63,80 \%$ \\
\hline
\end{tabular}


Bali Medika Jurnal.

Vol 7 No 2, 2020: 20-28

ISSN : 2615-7047

DOI: https://doi.org/10.36376/bmj.v7i2

Tidak obesitas

Total
59

163
$36,19 \%$

$100 \%$

Obesitas sentral diukur dengan lingkar pinggang. Lingkar pinggang dikatakan obesitas sentral jika $\geq 80 \mathrm{~cm}$. Berdasarkan tabel 2 diatas menunjukkan bahwa obesitas sentral pada remaja putri di SMP Ngeri 3 Abiansemal adalah sebanyak 59 responden $(36,19 \%)$.

Table 3. Distribusi frekuensi responden berdasarkan usia menarche pada remaja putri di SMP Negeri 3 Abiansemal

\begin{tabular}{c|c|c}
\hline Usia menarche & F & \% \\
\hline Menarche dini & 89 & $54,60 \%$ \\
\hline Menarche normal & 74 & $45,40 \%$ \\
\hline Total & 163 & $100 \%$ \\
\hline
\end{tabular}

Berdasarkan tabel 3 diatas menunjukkan bahwa responden yang mengalami menarche dini sebanyak 89 responden $(54,60 \%)$.

Table 4. Analisi hubungan obesitas sentral dengan kejadian menarche dini pada remaja putri di SMP Negeri 3 Abiansemal

\begin{tabular}{|c|c|c|c|c|c|c|c|}
\hline \multirow{2}{*}{ Obesitas } & \multicolumn{4}{|c|}{ Menarche } & \multicolumn{2}{c|}{ Total } & \multirow{2}{*}{$\mathrm{p}$} \\
\cline { 2 - 7 } & \multicolumn{2}{|c|}{ Dini } & \multicolumn{2}{c|}{ Normal } & \multicolumn{2}{c|}{} \\
\cline { 2 - 7 } & $\mathrm{f}$ & $\%$ & $\mathrm{f}$ & $\%$ & $\mathrm{f}$ & $\%$ & \\
\hline Tidak obesitas & 32 & $19,6 \%$ & 72 & $44,2 \%$ & 104 & $63,8 \%$ & \multirow{2}{*}{0,000} \\
\hline $\begin{array}{c}\text { Obesitas } \\
\text { sentral }\end{array}$ & 57 & $35,0 \%$ & 2 & $1,2 \%$ & 59 & $36,2 \%$ & \\
\hline Total & 89 & $54,6 \%$ & 74 & $45,5 \%$ & 163 & $100 \%$ & \\
\hline
\end{tabular}

Tabel 4 menunjukkan bahwa sebanyak 57 responden $(35,0 \%)$ yang mengalami obesitas sentral dan menarche dini pada remaja putri di SMP Negeri 3 Abiansemal. Hasil analisis juga didapatkan nilai $\mathrm{p}=0,000$ dimana $\mathrm{p}<\alpha$ $(0,000<0.05)$, maka $\mathrm{H}_{0}$ ditolak yang artinya ada hubungan bermakna antara obesitas sentral dengan kejadian menarche dini pada remaja putri di SMP Negeri 3 Abiansemal.

\section{PEMBAHASAN}

\section{Gambaran obesitas sentral}

Pada hasil penelitian ini didapatkan data yaitu sebanyak 57 responden $(34,97 \%)$ mengalami obesitas sentral dan yang tidak obesitas sentral sebanyak 104 responden $(63,80 \%)$. Berdasarkan penelitian yang dilakukan oleh Rofiq (2009) didapatkan hasil sebanyak $76,9 \%$ pada kelompok kasus memiliki lingkar pinggang $>80 \mathrm{~cm}$ sedangkan pada kelompok control sebanyak $38,5 \%$.

Penelitian ini juga sejalan dengan teori menurut Suastika (2008) dimana beberapa faktor yang dapat menyebabkan terjadinya kegemukan adalah faktor dari demografi yaitu usia dan jenis kelamin, faktor sosial budaya yaitu tingkat pendidikan, pendapatan, dan status perkawinan berdasarkan faktor biologis yaitu 
ada beberapa penyakit yang menyebabkan terjadinya obesitas seperti hipotiroidisme, sindroma chusing dan beberapa kelainan saraf yang menyebabkan seseorang banyak makan sedangkan faktor perilaku yaitu 1) Nutrisi, dimana kandungan lemak pada makanan dapat menyebabkan obesitas, 2) Alkohol, konsumsi alcohol yang berlebihan berhubungan dengan meningkatnya indeks massa tubuh, 3) aktivitas fisik, orang yang tidak bergerak lebih cepat meningkat berat badannya daripada orang-orang yang tidak aktif.

Menurut analisis peneliti banyaknya responden yang mengalami obesitas sentral pada remaja disebabkan salah satunya karena faktor nutrisi. Meningkatnya konsumsi junkfood dan fastfood dimana pada makanan tersebut kandungan lemaknya lebih banyak serta kandungan seratnya rendah dapat meningkatkan risiko terjadinya obesitas sentral pada remaja. Selain faktor nutrisi, minimnya aktivitas remaja menambah risiko terjadinya obesitas khususnya obesitas sentral pada remaja.

\section{Gambaran menarche dini pada remaja putri}

Hasil penelitian yang dilakukan di SMP Negeri 3 Abiansemal didapatkan hasil bahwa responden yang mengalami menarche dini sebanyak 89 responden $(54,60 \%)$ dan yang mengalami menarche normal sebanyak 74 responden $(45,50 \%)$. Berdasarkan penelitian yang dilakukan oleh Agres Vivi Susanti (2012) didapatkan prevalensi menarche dini sebanyak 23,6\% dari seluruh populasi siswi putri kelas VII di SMP 30 Semarang. Penelitian oleh Siti Astari Laajim (2013) didapatkan hasil penelitian dari 16 responden sebanyak 58 responden (39,7\%) mengalami menarche yang tidak normal di SMPN 8 Kota Gorontalo.

Menurut Gunardi \& Winkjosastro (2014), menarche dipengaruhi oleh faktor internal dan faktor eksternal. Faktor internal antara lain: a) Hormon, dimana terjadi peningkatan hormone estrogen dapat mempercepat pematangn organ genital dan muncul ciri-ciri seks pada anak, b) Genetik, saat timbulnya menarche juga kebanyakan ditentukan oleh pola dalam keluarga. Hubungan antara usia menarche sesame saudara kandung lebih erat daripada antara ibu dan anak perempuannya. Faktor eksternalnya antara lain: a) Gizi, makin baiknya nutrisi mempercepat usia menarche. Beberapa ahli mengatakan anak perempuan dengan jaringan lemak yang lebih banyak, lebih cepat mengalami menarche daripada anak yang kurus, b) Sosial ekonomi, status sosial yang tinggi dan keadaan ekonomi yang mapan akan membuat anak serba berkecukupan. Segala kebutuhan akan terpenuhi, seperti kebutuhan makakan yang bergizi dan akhirnya status nutrisi akan meningkat, c) Media Massa, rangsangan-rangsangan yang kuat dari luar, misalnya berupa filmfilm seks, buku-buku bacaan dan majalah-majalah bergambar seks, godaan dan rangsangan dari kaum pria, pengamatan secara langsung terhadap perbuatan seksual akan mempercepat munculnya menarche pada anak.

Menurut analisis peneliti banyaknya responden yang mengalmi menarche dini disebabkan oleh meningkatnya perkembangan teknologi yang menyebabkan semakin meluasnya pergaulan dari responden yang akan berdampak pada cepatnya pematangan dari organ reproduksi sehingga akan mempercepat munculnya menarche pada remaja putri.

\section{Hubungan obesitas sentral dengan kejadian menarche dini pada remaja putri di SMP Negeri 3 Abiansemal}


Berdasarkan hasil analisa hubungan obesitas sentral dengan kejadian menarche dini pada remaja putri didapatkan bahwa responden yang mengalami obesitas sentral dengan menarche dini sebanyak 57 responden $(35,0 \%)$ dan dengan menarche normal sebanyak 2 responden (1,2\%), sedangkan responden yang tidak mengalami obesitas sentral dengan menarche dini sebanyak 32 responden $(29,6 \%)$ dan dengan menarche normal sebanyak 72 orang $(44,2 \%)$.

Dari hasil uji statistik chi square menggunakan program komputerisasi dengan tingkat kemaknaan $5 \%$ atau $\alpha=0,05$ didapatkan nilai signifikan yaitu nilai $\mathrm{p}=0,000$ dimana $\mathrm{p}<\alpha$ yaitu $0,000<0,05$ sehingga $\mathrm{H}_{0}$ ditolak dan $\mathrm{H}_{\mathrm{a}}$ diterima, artinya ada hubungan antara obesitas sentral dengan kejadian menarche dini. Hal ini sejalan dengan teori menurut Wiknjosastro bahwa makin baiknya nutrisi mempercepat usia menarche. Anak perempuan dengan jaringan lemak lebih banyak, lebih cepat mengalami menarche daripada anak kurus.

Menurut Susanti (2012) konsumsi makanan tinggi lemak akan berakibat pada penumpukan lemak dalam jaringan adipose yang berkorelasi positif dengan peningkatan kadar leptin yang disekresikan dalam darah. Leptin ini berperan sebagai pengatur jaringan syaraf yang memicu pengeluaran Gonadotropin Releazing hormone (GnRH) hipotalamus. Pelepasan peptide GnRH hipotalamus akan mempengaruhi kematangan reproduksi. Selanjutnya hormone GnRH tersebut akan memicu pengeluaran Follicle Stimulating Hormone (FSH) dan Luteinizing Hormone (LH) di ovarium sehingga terjadi pematangan folikel dan pembentukan estrogen.

Penelitian ini juga diperkuat oleh penelitian dari Susanti (2012) dengan judul faktor risiko kejadian menarche dini pada remaja di SMPN 30 Semarang didapatkan hasil uji multivariate menunjukkan bahwa ada hubungan antara asupan lemak lebih dengan kejadian menarche dini pada remaja putri, setelah dikontrol oleh asupan serat dan kalsium. Menurut Susanti (2012) seseorang dengan riwayat asupan lemak lebih berisiko 4 kali lebih besar untuk mengalami menarche dini dibandingkan seseorang dengan asupan lemak tidak lebih.

Menurut analisis peneliti sendiri seiring dengan membaiknya standar kehidupan manusia akan berdampak pada kenaikan status ekonomi sehingga status nutrisi menjadi terpenuhi. Lemak yang berlebih didalam tubuh pada remaja akan berakibat pada cepatnya kematangan sistem reproduksi sehingga akan mempercepat terjadinya menarche atau terjadinya menarche dini.

\section{SIMPULAN}

\section{SIMPULAN DAN SARAN}

Berdasarkan hasil analisis dan pembahasan terhadap hasil penelitian yang dilakukan pada 163 responden di SMP Negeri 3 Abiansemal, dapat dirumuskan simpulan sebagai berikut: kejadian obesitas sentral pada remaja putri yang terjadi di SMP Negeri 3 Abiansemal adalah sebanyak 59 responden. Sedangkan kejadian menarche dini pada remaja putri yang terjadi di SMP Negeri 3 Abiansemal sebanyak 89 responden. Hasil uji Chi Square didapatkan nilai p value sebesar 0,000 dari tingkat signifikansi ditentukan yaitu 0,05 , hasil ini menunjukkan ada hubungan yang bermakna antara obesitas sentral dengan kejadian menarche dini pada remaja putri di SMP Negeri 3 Abiansemal. Adapun keterbatasan dalam penelitian ini 
adalah ketidakmampuan mengontrol faktor-faktor yang mempengaruhi menarche seperti: hormone, genetic, social ekonomi dan media masa.

\section{SARAN}

Berdasarkan hasil penelitian yang telah didapatkan ada beberpa saran yang ingin penulis kemukakan untuk dipertimbangkan pelaksanaannya adalah sebagai berikut:

1. Kepada Unit Kesehatan Sekolah (UKS) di SMP Negeri 3 Abiansemal, agar memberikan penyuluhan mengenai gizi seimbangan sehingga dapat mengurangi terjadinya obesitas sentral yang berhubungan terjadinya menarche dini pada remaja putri agar dapat mengurangi dampak yang terjadi seperti, terdampak pada terhambatnya pertumbuhan, stress emosional dan peningkatan risiko terjadinya kanker payudara. Selain mengurangi dampak dari terjadinya menarche dini, dampak obesitas sentral seperti risiko akan terjadinya penyakit diabetes mellitus tipe 2 dan penyakit komplikasi dari sindrom metabolism (hipertensi, kolesterol tinggi, serangan jantung, stroke, kerusakan hati dan ginjal) juga dapat dicegah.

2. Kepada peneliti selanjutnya, sebaiknya mampu mengontrol seluruh faktorfaktor yang dapat mempengaruhi menarche seperti: hormon, genetik, sosial ekonomi, dan media masa dengan cara menambah variable-variabel penelitian dalam penelitian selanjutnya.

\section{DAFTAR PUSTAKA}

Gunardi, E. R., \& Winkjosastro, H. (2014). Ilmu Kandungan (3 ed.). Jakarta: PT Bina Pustaka Sarwono Prawirohardjo.

Karapanou, O., \& Papadimitriou, A. (2010). Determinants of menarche. Reproductive Biology and Endocrinology, 8(1), 115.

Notoatmodjo, S. (2007). Kesehatan Masyarakat Ilmu Dan Seni. Jakarta: Rineka Cipta.

Nursalam. (2013). Metodologi Penelitian Ilmu Kedokteran: Pendekatan Praktis. Jakarta: Salemba Medika.

Putri, R. L. D., \& Soenarnatalina, M. (2013). Analisis Faktor Hubungan Usia Menarche Dini. Jurnal Biometrika dan Kependudukan, 2(1).

Rofiq, A. H. S. (2009). Persentase Lemak Tubuh dan Lingkar Pinggang sebagai Faktor bagi Ketidakteraturan Siklus Menstruasi pada Remaja Putri. Skripsi. Universitas Diponegoro.

Rosidah, L. (2008). Gambaran Pengetahuan Remaja tentang Menstruasi Pertama pada Siswi SMP Harapan Desa Paya Bakung Kecamatan Hamparan Perak Tahun 2006. Skripsi. Akademi Kebidanan Helvetia Medan.

Suastika, K. (2008). Sindrom Metabolik Kumpulan Naskah Ilmiah Obesitas, Sindrom Metabolic, Diabetes, Dislipidemia, Penyakit Tiroid. Skripsi. Universitas Udayana.

Sunarto, \& Intan, D. M. (2010). Hubungan Kelebihan Berat Badan dengan Menarche Dini. Jurnal Penelitian Kesehatan Suara Forikes, 1(4).

Susanti, A. V. (2012). Faktor Risiko Kejadian Menarche Dini pada Remaja di SMP N 30 Semarang. Journal of Nutrition College, 1, 115-126. 
Bali Medika Jurnal.

Vol 7 No 2, 2020: 20-28

ISSN : 2615-7047

DOI: https://doi.org/10.36376/bmj.v7i2

Tolombot, K. J. M., Manampiring, A. E., \& Kepel, B. J. (2014). Prevalensi Obesitas Pada Remaja Di SMP Negeri 8 Manado. eBiomedik, 2(2).

Waryana. (2010). Gizi Reproduksi. Yogyakarta: Pustaka Rahima. 